\title{
THE EFFECT OF CALCINATION TEMPERATURE TO THE COMPOSITE CHARACTERISTICS OF $\mathrm{TiO}_{2} \mathrm{SiO}_{2}$ NANOPARTICLE
}

\author{
Della Dwi Ananda and Dina Kartika Maharani* \\ Department of Chemistry, Faculty of Mathematics and Natural Science, \\ Universitas Negeri Surabaya, Surabaya, Jl. Ketintang, Surabaya, 60231 \\ E-mail:dinakartika@unesa.ac.id
}

Received: 2 July 2020

Revised: 14 October 2020

Accepted: 21 October 2020

\begin{abstract}
THE EFFECT OF CALCINATION TEMPERATURE TO THE COMPOSITE CHARACTERISTICS OF TiO $\mathrm{SiO}_{2}$ NANOPARTICLE. Self-cleaning material is a material that utilizes the photocatalytic property to degrade organic and inorganic compounds with the help of UV light. One of the materials that have good photocatalytic property is $\mathrm{TiO}_{2}$, the photocatalytic property causes $\mathrm{TiO}_{2}$ to be amphiphilic: becomes hydrophilic when there is light and becomes hydrophobic when there is no light. The photocatalytic property of $\mathrm{TiO}_{2}$ can be improved with the addition of buffer material such as $\mathrm{SiO}_{2}$. $\mathrm{TiO}_{2} \mathrm{SiO}_{2}$ nanoparticle was synthesized using a sol-gel method with Titanium (IV) Isopropoxide (TTIP) precursors for $\mathrm{TiO}_{2}$ and Tetraethyl Orthosilicate (TEOS) precursors for $\mathrm{SiO}_{2}$ and followed by a variation of calcination temperature of $400{ }^{\circ} \mathrm{C}, 450{ }^{\circ} \mathrm{C}, 500{ }^{\circ} \mathrm{C}$, and $550{ }^{\circ} \mathrm{C}$ for 2 hours. $\mathrm{TiO}_{2} \mathrm{SiO}_{2}$ composite was synthesized using composition $\mathrm{TiO}_{2}$ sol $75 \%$ and $\mathrm{SiO}_{2} 25 \%$. The result of the synthesis $\mathrm{TiO}_{2} \mathrm{SiO}_{2}$ composite was characterized by Fourier Transform Infra-Red (FT-IR) instrument to determine the functional groups in the composites and X-Ray Diffraction (XRD) instruments to determine the phase, crystallite size and degree of crystallinity in the composite. The purpose of this research is to synthesized $\mathrm{TiO}_{2} \mathrm{SiO}_{2}$ nanoparticle as a self-cleaning agent with variation of the calcination temperature, to obtain composite characteristics that can support self cleaning. The self-cleaning ability was based on a produced composite characteristic of $\mathrm{TiO}_{2} \mathrm{SiO}_{2}$. The result of FTIR characterization showed that at calcination temperature of $400{ }^{\circ} \mathrm{C}, 450{ }^{\circ} \mathrm{C}, 500{ }^{\circ} \mathrm{C}$, and $550{ }^{\circ} \mathrm{C}$ there was a Ti$\mathrm{O}$-Si bond at the peak of $948.91 \mathrm{~cm}^{-1}, 950.77 \mathrm{~cm}^{-1}, 941.13 \mathrm{~cm}^{-1}, 942.13 \mathrm{~cm}^{-1}$. The result of XRD characterization showed that at the temperature of $400^{\circ} \mathrm{C}$ had the best characteristics, the $75.27 \%$ anatase phase and brookite phase $24.72 \%$. Calcinations temperature $400^{\circ} \mathrm{C}$ had best degree of crystallinity of $91.66 \%$.
\end{abstract}

Keywords: $\mathrm{TiO}_{2} \mathrm{SiO}_{2}$ nanoparticles, Sol-gel, Calcination temperature, Self cleaning

\begin{abstract}
ABSTRAK
PENGARUH SUHU KALSINASI TERHADAP KARAKTERISTIK KOMPOSIT NANOPARTIKEL TiO $\mathbf{S i O}_{2}$. Material self cleaning adalah material yang memanfaatkan sifat fotokatalis untuk mendegradasi senyawa organik dan anorganik dengan bantuan sinar UV. Salah satu material yang memiliki sifat fotokatalis baik yaitu $\mathrm{TiO}_{2}$, sifat fotokatalis menyebabkan $\mathrm{TiO}_{2}$ bersifat ampifilik yaitu hidrofilik saat ada cahaya dan hidrofobik saat tidak ada cahaya. Sifat fotokatalis $\mathrm{TiO}_{2}$ dapat ditingkatkan dengan menambahkan material penyangga seperti $\mathrm{SiO}_{2}$. Sintesis nanopartikel $\mathrm{TiO}_{2} \mathrm{SiO}_{2}$ menggunakan metode sol-gel dengan prekursor Titanium (IV) Isopropoxide (TTIP) untuk $\mathrm{TiO}_{2}$ dan prekursor Tetraethyl Orthosilicate (TEOS) untuk $\mathrm{SiO}_{2}$, diikuti dengan variasi suhu kalsinasi $400{ }^{\circ} \mathrm{C}, 450{ }^{\circ} \mathrm{C}, 500{ }^{\circ} \mathrm{C}$, dan $550{ }^{\circ} \mathrm{C}$ selama 2 jam. Komposit $\mathrm{TiO}_{2} \mathrm{SiO}_{2}$ disintesis dengan perbandingan komposisi sol $\mathrm{TiO}_{2} 75 \%$ dan $\mathrm{SiO}_{2} 25 \%$. Komposit $\mathrm{TiO}_{2} \mathrm{SiO}_{2}$ yang telah disintesis dikarakterisasi dengan Fourier Transform Infra Red (FTIR) untuk mengetahui gugus fungsional
\end{abstract}


dalam komposit dan X-Ray Diffraction (XRD) untuk menentukan fasa, ukuran kristal dan derajat kristalinitas komposit. Penelitian ini bertujuan untuk melakukan sintesis nanopartikel $\mathrm{TiO}_{2} \mathrm{SiO}_{2}$ sebagai agen self cleaning dengan memvariasi suhu kalsinasi, agar diperoleh komposit dengan karakteristik yang dapat mendukung sifat self cleaning. Kemampuan self-cleaning didasarkan pada karakteristik komposit $\mathrm{TiO}_{2} \mathrm{SiO}_{2}$ yang dihasilkan. Hasil karakterisasi FTIR menunjukkan bahwa pada suhu kalsinasi $400{ }^{\circ} \mathrm{C}, 450{ }^{\circ} \mathrm{C}, 500{ }^{\circ} \mathrm{C}$, dan $550{ }^{\circ} \mathrm{C}$ terdapat ikatan Ti-O-Si pada puncak $94.91 \mathrm{~cm}^{-1}, 950.77 \mathrm{~cm}^{-1}, 941.13 \mathrm{~cm}^{-1}, 942.13 \mathrm{~cm}^{-1}$. Hasil karakterisasi XRD menunjukkan bahwa pada suhu $400{ }^{\circ} \mathrm{C}$ memiliki karakteristik terbaik yaitu fasa anatase $75.27 \%$ dan fasa brookite $24.72 \%$. Suhu kalsinasi $400{ }^{\circ} \mathrm{C}$ memiliki derajat kristalinitas terbaik yaitu sebesar $91.66 \%$.

Kata kunci: Nanopartikel $\mathrm{TiO}_{2} \mathrm{SiO}_{2}$, Sol-gel, Suhu kalsinasi, Self cleaning

\section{INTRODUCTION}

Nanotechnology is currently developing rapidly in all vital areas of science and technology such as electronics, aviation, defense, medicine and health. This relates to modeling, synthesis, characterization, and application of materials and equipment nanometer scale. The physical, chemical and biological properties of nanoscale differ from the properties of atoms and molecules in large materials. Therefore, it can provides an opportunity to develop a new class of advanced materials that have high-tech applications [1].

One of the nanomaterial is $\mathrm{TiO}_{2}$ and $\mathrm{SiO}_{2}$. Nanoparticle composite of $\mathrm{TiO}_{2} \mathrm{SiO}_{2}$ was synthesized by using sol gel method [2]. Sol gel method has advantages of sustainable homogeneity, can be conducted in room temperature, strengthening interaction between main semiconductor and buffer material. The steps of sol gel process are hydrolysis, condensation, aging, drying, and calcinations [3]. The last step is calcination, a heating process which aim to make photocatalyst's surface structure stronger, moreover organic and inorganic polluter in the catalyst can be eliminated during this process [4]. Calcination temperature has an effect on phase composition, crystals size, degree of crystallinity, and the amount of energy of semiconductor material band gap that was produced. $\mathrm{TiO}_{2}$ would have change of crystal structure if the calcination temperature increased. The crystals size would decrease with the increasing calcination temperature, thus photocatalytic activity going better in degrading a compound [5].

Calcination temperature affects the type of crystals formed. The anatase crystal phase was formed at a temperature of $400{ }^{\circ} \mathrm{C}$ and the growth of anatase crystals increased along with the increase in calcination temperature, at a temperature of $400-600{ }^{\circ} \mathrm{C}$ rutile nucleation occurred [6]. At a temperature of $600-900^{\circ} \mathrm{C}$, rutile crystal phase growth occurs and grows slowly as the calcination temperature increases [7]. The range of
UV rays absorbed by rutile is greater, but anatase has a greater photocatalytic activity. This is due to the difference in the energy structure between the two types of crystals, where the conduction band of the anatase crystals is closer to valence band so the reduction strength of the anatase crystals is greater than that of rutile [8]. Calcination temperature has affects on crystal size of $\mathrm{TiO}_{2} \mathrm{SiO}_{2}$ composites. When the calcination temperature higher, the smaller size of the crystals formed, this is because the diffusion of atoms becomes faster, which accelerates the crystallinity and forms a smaller crystal size. Based on other research results, each calcination temperature variation has a different crystal size, at $250^{\circ} \mathrm{C}$ has a crystal size of $50.59 \mathrm{~nm}, 300^{\circ} \mathrm{C}$ has a crystal size $23.64 \mathrm{~nm}, 400^{\circ} \mathrm{C}$ has a crystal size $22.85 \mathrm{~nm}$ and $500^{\circ} \mathrm{C}$ has a crystal size $20.78 \mathrm{~nm}$ [9].

Compounding $\mathrm{TiO}_{2}$ with $\mathrm{SiO}_{2}$ was done to increase adsorption ability and decrease recombination, so that photocatalytic activity of $\mathrm{TiO}_{2}$ can increase and decompose organic polluter [1]. Adsorption activity of $\mathrm{TiO}_{2}$ can be increased by adding buffer material with large surface area and high porosity [3]. $\mathrm{SiO}_{2}$ is a catalyst material that stable in high temperature and good mechanical resistance so that photocatalytic ability of $\mathrm{TiO}_{2}$ can be sustained. $\mathrm{SiO}_{2}$ has large surface area, it has hydroxyl group on its surface which work for adsorption side [10]. Addition of $\mathrm{SiO}_{2}$ to $\mathrm{TiO}_{2}$ can reduce the crystal's size, thus can increase the surface area of $\mathrm{TiO}_{2}$. The increase of surface area caused the increasing amount of active side, which is hole $\left(\mathrm{h}^{+}\right)$as an acceptor and electron $\left(\mathrm{e}^{-}\right)$as a donor absorbed and participate in reduction-oxidation reaction, thus its photocatalytic activity was increasing [11]. $\mathrm{SiO}_{2}$ can increase adsorption surface by water and hydroxyl group that was adsorbed and photocatalytic activity, because phase transformation from anatase to rutile was hampered by thermal stability and can be increased with titania silica oxide. The addition of $\mathrm{SiO}_{2}$ to $\mathrm{TiO}_{2}$ can act as a barrier 
and delay of $\mathrm{C}-\mathrm{C}$ bond on polymer matrix [12]. The combination of $\mathrm{TiO}_{2} \mathrm{SiO}_{2}$ is expected to produce a material that has good crystal size, phase composition and degree of crystallinity.

In this research, the addition of $\mathrm{SiO}_{2}$ to $\mathrm{TiO}_{2}$ made $\mathrm{TiO}_{2} \mathrm{SiO}_{2}$ composite have three unique characteristics physically and chemically, which are photocatalyst with mix of supporting effect and quantum size effect, acid catalyst that associated with new acid site generation [10]. The effect of calcination temperature also supports the properties of the crystal size, degree of crystallinity, and phase composition of the $\mathrm{TiO}_{2} \mathrm{SiO}_{2}$ composite. According to the explanation above, the researcher has conducted research about the synthesis of $\mathrm{TiO}_{2} \mathrm{SiO}_{2}$ using sol gel method with variation of calcination temperature at $400{ }^{\circ} \mathrm{C}, 450{ }^{\circ} \mathrm{C}, 500{ }^{\circ} \mathrm{C}, 550{ }^{\circ} \mathrm{C}$. The temperature is used because the $\mathrm{TiO}_{2} \mathrm{SiO}_{2}$ composite has the best characteristics among the temperature of 400 $550{ }^{\circ} \mathrm{C}$. The characterization of nanoparticle of $\mathrm{TiO}_{2} \mathrm{SiO}_{2}$ was tested using XRD and FTIR instrument.

\section{EXPERIMENTAL METHOD}

\section{Materials and Instruments}

Nanoparticle composite of $\mathrm{TiO}_{2} \mathrm{SiO}_{2}$ was synthesized by using sol gel method. Sol-gel method is an alternative method which is good for the synthesis of silica and titania nanoparticles, it can adjust the geometric structure, degree of cristallinity, phase composition and particle size [13]. The steps of sol gel process are hydrolysis, condensation, aging, drying, and calcination. The use of the sol gel method was chosen because it is relatively easy and can produce homogeneous $\mathrm{TiO}_{2} \mathrm{SiO}_{2}$ nanocomposites using tetraethoxysilane (TEOS) precursors and $\mathrm{TiO}_{2}$ nanoparticles and can grow on the surface of $\mathrm{TiO}_{2}$ nanoparticles [14]. The calcinations temperature affects the final composite characteristics. The materials used in this research are titanium (IV) isopropoxide (TTIP, Sigma Aldrich 98\%), tetraethyl orthosilicate (TEOS, Sigma Aldrich 98\%) were obtained from China, aquades, ethanol (Merck, 99\%), hydrochloric acid (HCl, Merck, 37\%), glacial acetic acid were obtained from Indonesia.

The tools used in this study are glass, dropper pipette, beaker, measuring cup, hot plate stirrer, magnetic stirrer, spatula, watch glass, mortar and pestle, analytical balance. Furnace, oven (Binder, Germani), ultrasonicator (Ultrasonic Power 540) were done in anorganic laboratory of Unesa, Fourier Transform Infrared Spectrophotometer
(Shimadzu 8021), X-Ray Diffraction (Shimadzu XRD 6000) were done in material and metallurgy laboratory of ITS. $\mathrm{TiO}_{2} \mathrm{SiO}_{2}$ composite was characterized by Fourier Transform Infra-Red (FT-IR) instrument to determine the functional groups in the composites and X-Ray Diffraction (XRD) instruments to determine the phase, crystallite size and degree of crystallinity in the composite.

\section{Method and Procedure}

\section{$\mathrm{TiO}_{2}$ sol synthesis}

The synthesis of $\mathrm{TiO}_{2}$ was carried out by sol-gel method. Started with $2 \mathrm{~mL}$ of glacial acetic acid as a catalyst, mixed with $5 \mathrm{~mL}$ of ethanol p.a as a solvent and $3.2 \mathrm{~mL}$ of TTIP precursor was added drop by drop at a time while in ultrasonicator for 15 minutes. The result is a clear, light yellow solution which then let it sit for 24 hours until it became gel.

\section{$\mathrm{SiO}_{2}$ sol synthesis}

The synthesis of $\mathrm{SiO}_{2}$ was carried out by sol-gel method. Started with adding $5 \mathrm{~mL}$ of tetraethyl orthosilicate (TEOS) mixed with $5 \mathrm{~mL}$ of ethanol p.a. then put it to stirrer for 10 minutes at $300 \mathrm{rpm}$. Next, 3-4 drops of $0.1 \mathrm{M} \mathrm{HCl}$ solution were put into $10 \mathrm{~mL}$ of aquades then stirred homogeneously. After that the mix of $\mathrm{HCl}$ solution and aquades were poured into TEOS and ethanol p.a solution and put it to stirrer for five minutes at 300 rpm. Next, the solution was heated at $60{ }^{\circ} \mathrm{C}$ for approximately 90 minutes and put it to stirrer at $300 \mathrm{rpm}$. Let it sit for 24 hours until it became gel.

\section{Composite synthesis of $\mathrm{TiO}_{2} \mathrm{SiO}_{2}$}

The composite synthesis of $\mathrm{TiO}_{2} \mathrm{SiO}_{2}$ was started by mixing $\mathrm{TiO}_{2}$ and $\mathrm{SiO}_{2}$ sol with the composition of $75 \%$. Put it in the stirrer until $\mathrm{TiO}_{2} \mathrm{SiO}_{2}$ sol became homogeneous. Next, let it sit for 24 hours in room temperature for aging process. Then the solution was dried in oven at $110{ }^{\circ} \mathrm{C}$ for 4 days until it crystallized. After that, the crystal of $\mathrm{TiO}_{2} \mathrm{SiO}_{2}$ composite was mashed until it became powder and calcinated the powder in 400 ${ }^{\circ} \mathrm{C}, 450{ }^{\circ} \mathrm{C}, 500^{\circ} \mathrm{C}$ and $550{ }^{\circ} \mathrm{C}$.

\section{Characterization of $\mathrm{TiO}_{2} \mathrm{SiO}_{2}$ composite using XRD}

$1 \mathrm{mg}$ of each calcination variation of $\mathrm{TiO}_{2} \mathrm{SiO}_{2}$ composite powder was taken to be tested and analysed using XRD with $2 \theta$ between $3^{\circ}-100^{\circ}$. 


\section{Characterization of $\mathrm{TiO}_{2} \mathrm{SiO}_{2}$ composite using FTIR}

$1 \mathrm{mg}$ of each calcination variation of $\mathrm{TiO}_{2} \mathrm{SiO}_{2}$ composite powder was taken to be tested and analysed using FTIR.

\section{RESULT AND DISCUSSION}

\section{$\mathrm{TiO}_{2}$ synthesis}

The addition of TTIP precursor can speed up the hydrolysis process because TTIP has short alkoxy chain. The shorter the alkoxy chain (M-O-R) then the precursor reactivity is bigger and sol-gel hydrolysis process in faster, thus carbon atom chain in the precursor easily reacted with siloxane group ( $\mathrm{Si}-\mathrm{O}-\mathrm{Si}$ ) forming $\mathrm{Si}-\mathrm{O}-\mathrm{Ti}$ bond. The longer the ligand (-OR) in the precursor, the slower the hydrolysis rate. It is because of steric hindrance due to the longer $\mathrm{R}$ chain, therefore the transfer of ligand (-OR) with hydroxyl group (-OH) is slower [15].

In the synthesis process, ethanol solution acted as solvent. The type of solvent affects the hydrolysis process. Solvents that are often used are methanol and ethanol. Methanol has a shorter $\mathrm{C}$ chain than ethanol, so methanol has a greater degree of polarity. More polar solvents cause the hydrolysis process to be faster and more stabilize the Ti-OH group, the more stable the nucleus is, the condensation reaction will spread throughout the core and smaller the crystal size is formed [16].

When $\mathrm{TiO}_{2}$ sol is irradiated with ultrasonic waves, the solution creates a collision between the constituent particles under high pressure. The ultrasonication time affect the particle size, longer the ultrasonication time the particle size to be more homogeneous and smaller, which ultimately leads to a stable nanoparticle size and less agglomeration [17]. The ultrasonic times of 120 minutes and 180 minutes had crystal sizes of $13.64 \mathrm{~nm}$ and $11.84 \mathrm{~nm}$. Caused by the shock wave during ultrasonication separate the agglomeration of particles and a perfect disperse occurs with the addition of a factor as a stabilizer [18]. Based on other research [19], the type of solvent and the time of ultrasonication have an effect on the crystal size and characterization results.

Glacial acetic acid acted as catalyst to speed up the hydrolysis process, both aimed to help the formation process of $\mathrm{TiO}_{2}$. With the condition inside of ultrasonicator, the solution's components would have increase of activity with the movement of ultrasonic wave under water, so the micro-mixing process in the solvent will be formed [20]. Condensation process occurred which would produce inorganic compound and formed $\mathrm{TiO}_{2} \cdot \mathrm{xH}_{2} \mathrm{O}$. The aim of aging process is to strengthen the result gel with interpolymer bond.

\section{$\mathrm{SiO}_{2}$ sol synthesis}

This synthesis process, ethanol solution acted as solvent. The type of solvent affects the hydrolysis process. Solvents that are often used are methanol and ethanol. Methanol has a shorter $\mathrm{C}$ chain than ethanol, so methanol has a greater degree of polarity. More polar solvents cause the hydrolysis process to be faster and more stabilize the Ti-OH group, the more stable the nucleus is, the condensation reaction will spread throughout the core so that the smaller the crystal size is formed [16]. Glacial acetic acid acted as catalyst to speed up hydrolysis process, aquades helped to hydrolyse TEOS in acidic state, all three aimed to help the formation process of $\mathrm{SiO}_{2}$. To accelerate the hydrolysis process without eliminating the solvent inside. In gel formation, there was $\mathrm{SiO}_{2}$ tissue surrounded by pores filled with ethanol and $\mathrm{H}_{2} \mathrm{O}$ [8].

\section{$\mathrm{TiO}_{2} \mathrm{SiO}_{2}$ composite synthesis}

TTIP act as the hydrolysis agent and group of $\mathrm{Si}-\mathrm{O}-\mathrm{Si}$ in the polymer can be formed, it can form bond of Ti-O-Si. In condensation process, there was a change from sol to gel. The used $110^{\circ} \mathrm{C}$ is to dried and evaporate the solvent leftover in the gel and gel that has cross linking addition in unreacted group of -OH and -OR, thus it can form good solids [15]. The anatase crystal phase was formed at a temperature of $400{ }^{\circ} \mathrm{C}$ and the growth of anatase crystals increased along with the increase in calcination temperature, at a temperature of $400-600^{\circ} \mathrm{C}$ rutile nucleation occurred [6]. At a temperature of $600-900{ }^{\circ} \mathrm{C}$, rutile crystal phase growth occurs and grows slowly as the calcination temperature increases [7]. Based on research from other journals [9], at a calcination temperature of $250-350{ }^{\circ} \mathrm{C}$ the crystallite sizes were $50.59 \mathrm{~nm}, 42.42 \mathrm{~nm}$ and $35.94 \mathrm{~nm}$. At temperatures over $550^{\circ} \mathrm{C}$, the crystal size is not optimal.

\section{$\mathrm{TiO}_{2} \mathrm{SiO}_{2}$ Composite Phase Characterization}

The result of X-ray diffractogram of $\mathrm{TiO}_{2} \mathrm{SiO}_{2}$ was provided in Figure 1. 


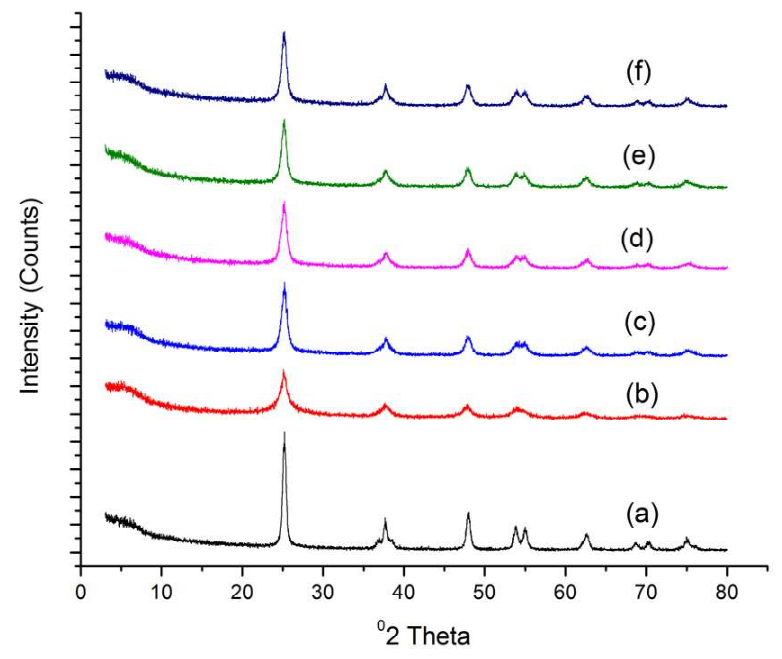

Figure 1. X-ray diffractogram of: (a) standard $\mathrm{TiO}_{2}$ (b) $\mathrm{TiO}_{2} \mathrm{SiO}_{2}$ without caltination (c) $\mathrm{TiO}_{2} \mathrm{SiO}_{2} 400{ }^{\circ} \mathrm{C}$ (d) $\mathrm{TiO}_{2} \mathrm{SiO}_{2} 450{ }^{\circ} \mathrm{C}$ (e) $\mathrm{TiO}_{2} \mathrm{SiO}_{2} 500{ }^{\circ} \mathrm{C}$ (f) $\mathrm{TiO}_{2} \mathrm{SiO}_{2} 550{ }^{\circ} \mathrm{C}$

According to XRD diffractogram in Figure 1, it shows that $\mathrm{TiO}_{2} \mathrm{SiO}_{2}$ composite that was produced has crystalline characteristic, marked with $2 \theta$ angle that shows sharp and pointed peaks. Crystalline characteristic is acquired by comparing $2 \theta$ value or $\mathrm{d}(\mathrm{A})$ in each peak of the XRD diffractogram result using Joint Crystal Powder Diffraction Standard (JCPDS) card. Each calcinations temperature of $\mathrm{TiO}_{2} \mathrm{SiO}_{2}$ composite shows crystalline characteristic because the ratio of $\mathrm{TiO}_{2} \mathrm{SiO}_{2}$ is dominated by $\mathrm{TiO}_{2}$ for $75 \%$.

The addition of $\mathrm{SiO}_{2}$ into $\mathrm{TiO}_{2}$ caused $\mathrm{SiO}_{2}$ enter the gaps of $\mathrm{TiO}_{2}$ structure and the result is it might break $\mathrm{TiO}_{2}$ crystal structure. The atoms that formed in the composite during the calcination process was not stable when subjected to heat flow. Those two things made the decrease of intensity and the shift of $2 \theta$ to the lower direction [14]. XRD pattern in Figure 1(c) to 1(f) has almost the same peak intensity.

In $400{ }^{\circ} \mathrm{C}, 450{ }^{\circ} \mathrm{C}, 500{ }^{\circ} \mathrm{C}, 500{ }^{\circ} \mathrm{C}$ calcination $\mathrm{TiO}_{2} \mathrm{SiO}_{2}$ composite, the highest peak occurred at the angle of $25.09^{\circ}$ followed by peak at $37.80^{\circ} 53.90^{\circ}$ which shows the anatase phase that match with JCPDS number 1272. Other than anatase phase, $\mathrm{TiO}_{2} \mathrm{SiO}_{2}$ composite with peak at the angle of $47.87^{\circ}$ and $68,78^{\circ}$ shows brookite phase, it matched with JCPDS number 29-1360. At the angle of $62.74^{\circ}$, it shows the occurrence of rutile phase that match with JCPDS number 21-1276. At the temperature of $400^{\circ} \mathrm{C}$, it has anatase phase composition of $75.27 \%, 54.92 \%$ at $450{ }^{\circ} \mathrm{C}, 56.44 \%$ at $500{ }^{\circ} \mathrm{C}, 50.58 \%$ at $550{ }^{\circ} \mathrm{C}$. From each of calcination temperature variation shows the more dominant percentage of anatase phase composition than brookite and rutile phase. For more information, composition phase percentage is shown in
Table 1 . At $400{ }^{\circ} \mathrm{C}$ the optimum crystalline phase of anatase is formed, when the calcination temperature increases $450-550{ }^{\circ} \mathrm{C}$, the anatase phase begins unstable and transforms into rutile. TS has a greater rutile phase composition than standard $\mathrm{TiO}_{2}, \mathrm{SiO}_{2}$ should inhibit the transformation of $\mathrm{TiO}_{2}$ from the anatase phase to rutile [21].

According to XRD synthesis result data, it shows that anatase phase of $\mathrm{TiO}_{2} \mathrm{SiO}_{2}$ composite has bigger composition than standard $\mathrm{TiO}_{2}$. The composite of TS $400{ }^{\circ} \mathrm{C}$ has the biggest anatase phase composition compared to TS, TS $450{ }^{\circ} \mathrm{C}$, TS $500^{\circ} \mathrm{C}$, TS $550^{\circ} \mathrm{C}$. The best formed anatase phase was at the calcination temperature of $400{ }^{\circ} \mathrm{C}$, a higher calcination temperature caused the produced anatase phase to be smaller and starting to be unstable, therefore there is a change of crystal form to rutile and brookite. Rutile phase in TS $550{ }^{\circ} \mathrm{C}$ composite was bigger than TS, TS $450{ }^{\circ} \mathrm{C}$, TS 500 ${ }^{\circ} \mathrm{C}$ composite. At a high calcination temperature, $\mathrm{SiO}_{2}$ moves to gaps of $\mathrm{TiO}_{2}$ crystal structure thus $\mathrm{TiO}_{2}$ renovation process was occurred that caused change from anatase phase to rutile phase [9]. Based on mentioned above, $\mathrm{TiO}_{2} \mathrm{SiO}_{2}$ composite at $400{ }^{\circ} \mathrm{C}$ showed the best photocatalytic activity, marked with the biggest anatase phase among every variation of calcination temperature [14].

\section{Characterization of Crystallinity Degree of $\mathrm{TiO}_{2} \mathrm{SiO}_{2}$ Composite}

Result percentage that shows how much crystalline or amorphous content in a material is called degree of crystallinity. According to degree of crystallinity calculation, it was found that $400{ }^{\circ} \mathrm{C}$ calcination temperature $\mathrm{TiO}_{2} \mathrm{SiO}_{2}$ composite has $91.66 \%$ degree of crystallinity. At calcination temperature of 450 ${ }^{\circ} \mathrm{C}$ showed degree of crystallinity of $89.74 \%$. At calcination temperature of $500{ }^{\circ} \mathrm{C}$ and $550{ }^{\circ} \mathrm{C}$ showed degree of crystallinity of $90.90 \%$ and $88.70 \%$. For TS and $\mathrm{TiO}_{2}$ standard sample, they have $83.33 \%$ and $90.74 \%$ for degree of crystallinity. Those acquired result shows that degree of crystallinity was increasing and decreasing as the calcination temperature got higher. However, degree of crystallinity supposed to be increasing as the calcination temperature got higher [9]. Matching with another research data that state the degree of crystallinity increase as the calcination temperature got higher [22].

Based on the obtained data, sample at calcination temperature of $400^{\circ} \mathrm{C}$ has the highest degree of crystallinity. It is because of the biggest anatase phase 
composition is sample TS $400{ }^{\circ} \mathrm{C}$. Anatase crystal has a good degree of crystallinity because of electron transport in anatase crystal is relatively faster than rutile and brookite crystal [6,7]. A good degree of crystallinity will influence the characteristics of $\mathrm{TiO}_{2} \mathrm{SiO}_{2}$ composite, the bigger the degree of crystallinity, its photocatalytic ability is also increasing.

\section{Characterization of $\mathrm{TiO}_{2} \mathrm{SiO}_{2}$ Composite Crystal Size}

Based on data of synthesized diffractogram XRD, $\mathrm{TiO}_{2} \mathrm{SiO}_{2}$ composite crystal's size showed a raise as the increase of calcination temperature. At calcination temperature of $400{ }^{\circ} \mathrm{C}$ showed the crystal's size was at $18.30 \mathrm{~nm}$, then decreased to $16.51 \mathrm{~nm}$ at $450^{\circ} \mathrm{C}$. Crystal's size at $500^{\circ} \mathrm{C}$ and $550{ }^{\circ} \mathrm{C}$ was increasing at $19.58 \mathrm{~nm}$ and $31.47 \mathrm{~nm}$. The smallest crystal's size was when the composite was at calcination temperature of $450{ }^{\circ} \mathrm{C}$.

Table 1. Data of phase composition and synthesized crystal size

\begin{tabular}{|c|c|c|c|c|}
\hline \multirow{2}{*}{ Material } & \multicolumn{3}{|c|}{ Phase Composition (\%) } & \multirow{2}{*}{$\begin{array}{c}\text { Crystal } \\
\text { Size }(n m)\end{array}$} \\
\hline & Anatase & Rutil & Brookite & \\
\hline $\begin{array}{l}\mathrm{TiO}_{2} \\
\text { standar }\end{array}$ & 67.89 & 10.41 & 21.68 & 30.86 \\
\hline TS & 54.33 & 13.41 & 32.25 & 14.81 \\
\hline $\operatorname{IS~} 400^{\circ} \mathrm{C}$ & 75.27 & 0 & 24.72 & 18.30 \\
\hline $\operatorname{TS} 450^{\circ} \mathrm{C}$ & 54.92 & 10.77 & 34.29 & 16.51 \\
\hline $\operatorname{TS~} 500^{\circ} \mathrm{C}$ & 56.44 & 10.93 & 32.61 & 19.58 \\
\hline${\operatorname{TS~} 550^{\circ} \mathrm{C}}$ & 50.58 & 18.87 & 30.51 & 31.17 \\
\hline
\end{tabular}

According to research result in another journal, higher calcination temperature was supposed to make smaller crystal size, thus the structure of the crystal was more regular and the surface area was getting bigger [8]. At a temperature $550{ }^{\circ} \mathrm{C}$ has the largest crystal size. Several things that affect synthesize result are condition influence during synthesize, preparation method, the type of used precursor, and the type of interaction produced between $\mathrm{TiO}_{2}$ and $\mathrm{SiO}_{2}$. TTIP is a highly reactive precursor and sustain a rapid hydrolysis process, this cause composite formation with $\mathrm{SiO}_{2}$ during condensation process was fast [15]. Based on these, it possibly caused agglomeration between neighbouring particles due to fast reaction and increase of particle size distribution that cause the produced crystal's size was getting bigger as the calcination temperature increase [21]. Mixing process of $\mathrm{SiO}_{2}$ into $\mathrm{TiO}_{2}$ was not yet homogeneous, because the produced sol only mixed physically not chemically. That caused the crystal's size getting bigger in high calcination temperature.

Different calcination temperature on $\mathrm{TiO}_{2} \mathrm{SiO}_{2}$ composite was affecting the characteristics of the produced composite, the higher the calcination temperature the crystal size was getting lower as the decrease of anatase phase. At a temperature $550{ }^{\circ} \mathrm{C}$ has the largest crystal size, it possibly caused agglomeration between neighbouring particles due to fast reaction and increase of particle size distribution that cause the produced crystal's size was getting bigger as the calcination temperature increase. The increase of calcination temperature caused the decreasing of composite crystal's size and the surface area is increasing [14].

\section{Characterization of Functional Group of $\mathrm{TiO}_{2} \mathrm{SiO}_{2}$ Composite Using FTIR}

Characterization of functional group of $\mathrm{TiO}_{2} \mathrm{SiO}_{2}$ composite data is shown in Figure 2.

Based on FTIR result data in Figure 2 (c), (d), (e), (f) shows the peak in wavelength $3217.43 \mathrm{~cm}^{-1}, 3248.84$ $\mathrm{cm}^{-1}, 3245.92 \mathrm{~cm}^{-1}, 3254.85 \mathrm{~cm}^{-1}, 3299.08 \mathrm{~cm}^{-1}$ that shows the occurrence of $-\mathrm{OH}$ stretching vibration that caused by hydrogen bond from $\mathrm{Si}-\mathrm{OH}$ group. Wave number of TS $400{ }^{\circ} \mathrm{C}$ composites show absorption area of around $1640-1620 \mathrm{~cm}^{-1}$ that is $1637.08 \mathrm{~cm}^{-1}$. In those absorption areas show the occurrence of $-\mathrm{OH}$ bending vibration from hydroxyl because of the absence of hydrogen bond [14]. According to other research result, $-\mathrm{OH}$ bending vibration is in absorption area of $1600-1640 \mathrm{~cm}^{-1}$ [23].

$\mathrm{Si}-\mathrm{O}$ stretching vibration in $400{ }^{\circ} \mathrm{C}$ showed the absorption peak in the areas of $1055.97 \mathrm{~cm}^{-1}$. In wave numbers of $422.71 \mathrm{~cm}^{-1}$ showed Ti-O stretching vibration. Those result is almost as the same as research result, which is $\mathrm{Si}-\mathrm{O}$ bond is in the absorption area of 1050$1090 \mathrm{~cm}^{-1}$ and Ti-O bond is in the absorption area of 420 $460 \mathrm{~cm}^{-1}$ [23].

Wave number in $\mathrm{TiO}_{2} \mathrm{SiO}_{2}$ composite shows absorption area around 950-960 $\mathrm{cm}^{-1}$, based on FTIR result Ti-O-Si bond $400^{\circ} \mathrm{C}$ formed in absorption areas of 948.91 $\mathrm{cm}^{-1}$. Those areas showed low intensity peaks, it is because of the influence when synthesizing process and its preparation method, thus Ti-O-Si did not perfectly mix chemically (Ti-O-Si bond formation), but perfectly mixed physically (with interaction force not more than Van der Waals weak bond) [6]. As the calcination 

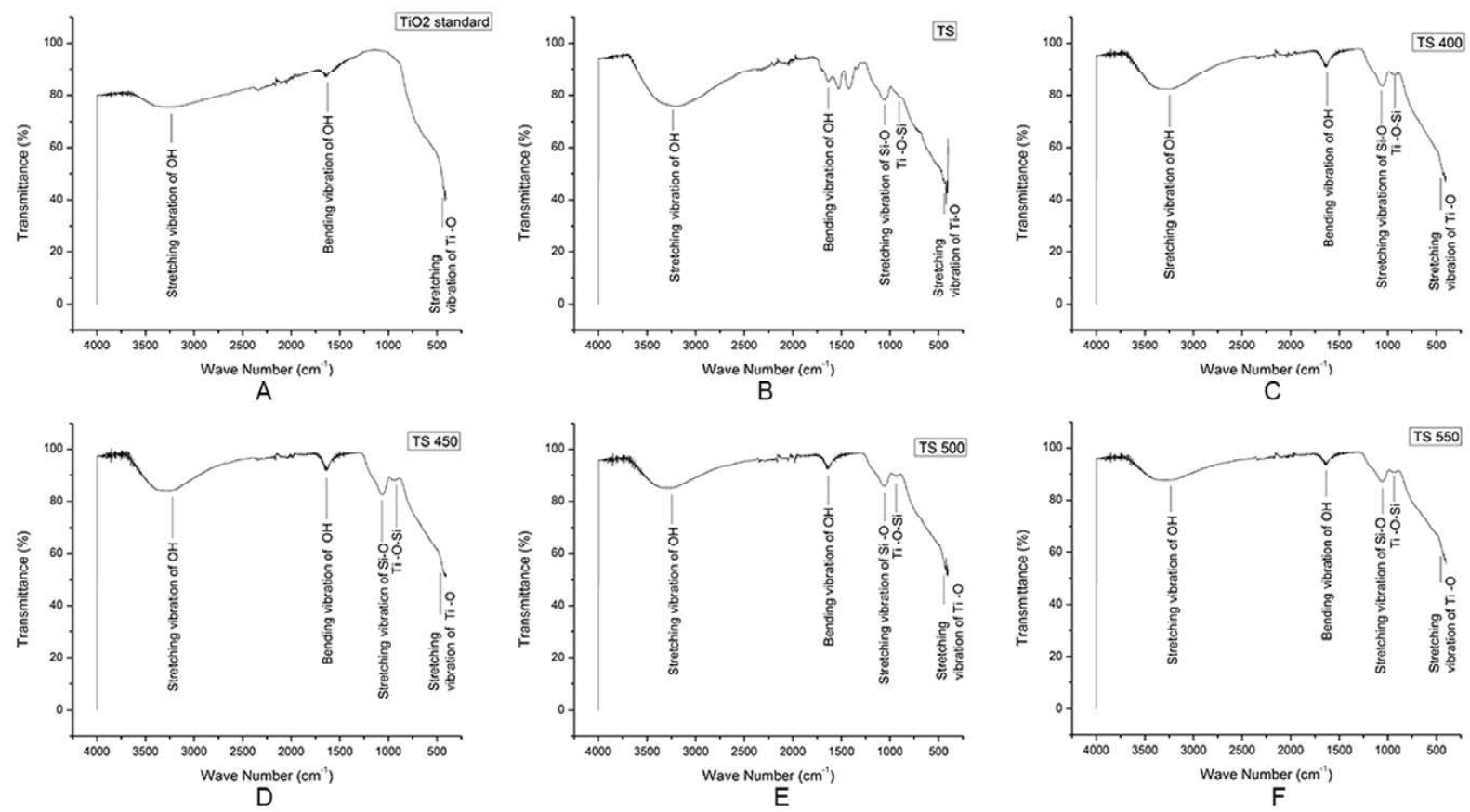

Figure 2. The result of FTIR: (a) $\mathrm{TiO}_{2}$ standard (b) $\mathrm{TiO}_{2}$ without calcination (c) $\mathrm{TiO}_{2} \mathrm{SiO}_{2} 400{ }^{\circ} \mathrm{C}$ (d) $\mathrm{TiO}_{2} \mathrm{SiO}_{2} 450^{\circ} \mathrm{C}$ (e) $\mathrm{TiO}_{2} \mathrm{SiO}_{2} 500{ }^{\circ} \mathrm{C}$ (f) $\mathrm{TiO}_{2} \mathrm{SiO}_{2} 550{ }^{\circ} \mathrm{C}$

temperature getting higher, it caused the peaks that consist of bending and stretching vibration of $\mathrm{O}-\mathrm{H}$ bond getting lower and decreasing its intensity. Table 2 shows absorption areas of wave number that formed form synthesized composite.

Based on Table 2, wave numbers of Ti-O-Si bond at a temperature of $400-550{ }^{\circ} \mathrm{C}$ have an insignificant increase and decrease. On higher calcination temperature has lower peak intensity, caused by effect on the ability of $\mathrm{TiO}_{2} \mathrm{SiO}_{2}$ in self-cleaning activities. Self cleaning activity depends on the peaks of Ti-O-Si bonds are formed. At a temperature of $400{ }^{\circ} \mathrm{C}$, it shows peak intensity reaches the optimum point, because at $450{ }^{\circ} \mathrm{C}$ has an increase peak and accompanied by a decrease at temperatures of $500^{\circ} \mathrm{C}$ and $550{ }^{\circ} \mathrm{C}$.

According to FTIR result in Figure 2, it shows that synthesized composite showed low peak intensity of Ti-O-Si. With $\mathrm{Si}\left(\mathrm{OC}_{2} \mathrm{H}_{5}\right)_{3}(\mathrm{OH})$ compound being there as a precursor during reaction process can affect crystallinity characteristics of the formed composite, causing $\mathrm{SiO}_{2}$ to be more amorphous [20]. FTIR result can be strengthen with diffractogram result on $2 \theta$ peak that showed that the addition of $\mathrm{SiO}_{2}$ in the composite can lower crystallinity characteristic of $\mathrm{TiO}_{2} \mathrm{SiO}_{2}$, thus it seems that $\mathrm{TiO}_{2}$ peak intensity before the addition of $\mathrm{SiO}_{2}$ was relatively higher marked with sharper and higher diffraction peak intensity.Based on that, composite with variation difference of calcination temperature does not significantly affect produced functional group.

\section{CONCLUSION}

The $\mathrm{TiO}_{2} \mathrm{SiO}_{2}$ nanocomposites has been synthesized by sol gel method. The characterization of composite showed the effect of calcinations to crystalite

Table 2. Functional group data that formed form synthesized composite

\begin{tabular}{|c|c|c|c|c|c|c|}
\hline \multirow{2}{*}{$\begin{array}{c}\text { Functional } \\
\text { Group }\end{array}$} & \multicolumn{6}{|c|}{ Wave Number $\left(\mathrm{cm}^{-1}\right)$} \\
\hline & $\mathrm{TiO}_{2}$ standard & $\mathrm{TiO}_{2}-\mathrm{SiO}_{2}$ & $\mathrm{TS} 400^{\circ} \mathrm{C}$ & $\mathrm{TS} 450^{\circ} \mathrm{C}$ & $\mathrm{TS} 500^{\circ} \mathrm{C}$ & $\mathrm{TS} 550^{\circ} \mathrm{C}$ \\
\hline $\begin{array}{l}\text { Stretching vibra- } \\
\text { tion of O-H from } \\
\text { Si-OH or Ti-OH }\end{array}$ & 3227.73 & 3217.43 & 3248.84 & 3245.92 & 3254.85 & 3299.08 \\
\hline $\begin{array}{l}\text { Bending vibra- } \\
\text { tion of O-H from } \\
\text { Si-OH or Ti-OH }\end{array}$ & 1654.00 & 1628.50 & 1637.08 & 1637.09 & 1636.98 & 1637.18 \\
\hline $\begin{array}{l}\text { Stretching vibra- } \\
\text { tion of Si-O } \\
\text { from Si-O-Si }\end{array}$ & - & 1050.48 & 1055.97 & 1062.24 & 1061.87 & 1056.87 \\
\hline $\begin{array}{l}\text { Stretching vibra- } \\
\text { tion of } \mathrm{Si}-\mathrm{O} \\
\text { from } \mathrm{Si}-\mathrm{O}-\mathrm{Si} \\
\end{array}$ & 418.83 & 439.14 & 422.71 & 417.30 & 429.36 & 424.28 \\
\hline $\begin{array}{c}\text { Bonds of Ti-O- } \\
\text { Si }\end{array}$ & - & 949.34 & 948.91 & 950.77 & 941.13 & 942.13 \\
\hline
\end{tabular}


sized, phase composition, degree of crystalinity and wave number. The optimum calcination temperature is $400{ }^{\circ} \mathrm{C}$ showed the best characteristic has $75.27 \%$ anatase phase composition and $24.72 \%$ brookite with crystal's size of $18.30 \mathrm{~nm}$ and degree of crystallinity of $91.66 \%$. The presence of $\mathrm{TiO}_{2} \mathrm{SiO}_{2}$ composite functional group in wave number of $948.91 \mathrm{~cm}^{-1}$ showed that there is bonds of Ti-O-Si.

\section{ACKNOWLEDGMENT}

Thank you for Unesa Instrumental Laboratory, Unesa Inorganic Chemistry Laboratory, ITS Material and Metallurgy Laboratory as a place to make the data of this research, also for colleagues who helped and directly involved in this research, thus this research can proceed well.

\section{REFERENCES}

[1]. A. Arie, and W. Sri. "Sintesis Nanosilika dengan Metode Sol-Gel dan Uji Hidrofobisitasnya pada Cat Akrilik". Indonesian Journal of Chemical Science, vol. 4, no. 3, 2015.

[2]. S. Sijia, D. Tongrong, D, Hao, C, Yin, and C, Wanting. "Preparation of $\mathrm{Nano}^{\mathrm{TiO}}{ }_{2}$ Coated $\mathrm{SiO}_{2}$ Microsphere Composite Material and Evaluation of Its Self-Cleaning Property". Journal Nanomaterials, vol. 7, no. 367, 2017.

[3]. S. F. Eksa. "Sintesis dan Karakterisasi $\mathrm{TiO}_{2} /$ Zeolit Variasi Komposisi dengan Metode Sol Gel”. Skripsi. UIN Maulana Malik Ibrahim, Indonesia, pp.15-18, 2018.

[4]. S. S. Juliet, S. Ramalingom, C. Ravidhas, and A. M. E. Raj. "Effect of Calcination Temperature on Titanium Oxide Nanocrystallites in the Anatase Phase Synthesized by Sol-Gel Route". IOSR Journal of Applied Physics, vol. 9, Issue 4, 2017.

[5]. R. Rohmah, and M. Zainuri. "Pengaruh Variasi Suhu Kalsinasi $\mathrm{SiO}_{2}$ Terhadap Sifat Kebasahan Pada Permukaan Hidrofobik". Jurnal Sains dan Seni ITS. vol. 5(2): pp.2337-3520, 2016.

[6]. W. Edy, F.W. Mahatmanti, and S. Priatmoko. "Pengaruh Jenis Prekursor dan Suhu Kalsinasi terhadap Karakteristik Komposit $\mathrm{TiO}_{2} \mathrm{SiO}_{2}$ dan Aplikasinya dalam Degradasi Rhodamin B". Jurnal Sains dan Teknologi, vol. 41, no. 1, 2015.

[7]. L. Wensheng, Z. Jiaxian, Y. Lianghong, and Z. Xinxiang. 2017. "Sol Gel Preparation of Self Cleaning $\mathrm{SiO}_{2}-\mathrm{TiO}_{2} / \mathrm{SiO}_{2}-\mathrm{TiO}_{2}$ Double Layer Anti
Reflective Coating for Solar Glass". Results in Physics, vol. 8, pp. 1-12, 2017.

[8]. R. Rohmah, and Z. Mochamad. "Pengaruh Variasi Temperatur Kalsinasi $\mathrm{SiO}_{2}$ terhadap Sifat Kebasahan pada Permukaan Hidrofobik". Jurnal Sains dan Seni Jurusan Fisika ITS, vol. 5(2): pp. 2337-3520, 2016.

[9]. L. Wensheng, Z. Jiaxian, Y. Lianghong, and Z. Xinxiang. "Sol Gel Preparation of Self Cleaning $\mathrm{SiO}_{2}-\mathrm{TiO}_{2} / \mathrm{SiO}_{2}-\mathrm{TiO}_{2}$ Double Layer Anti Reflective Coating for Solar Glass". Results in Physics, pp. 112, 2017.

[10]. S. Wahyuni and A.T. Prasetya. "Enhanced The Hydrophobic Surface and The Photo Activity of $\mathrm{TiO}_{2}-\mathrm{SiO}_{2}$ Composite”. Journal of Material Science and Engineering. vol. 172, 2017.

[11]. S. Chelbi1, D. Djouadi, A. Chelouche, L. Hammiche1, T. Touam, and A. Doghmane. "Effects of Ti Precursor Concentration and Annealing Temperature on Structural and Morphological Properties of $\mathrm{TiO}_{2}$ Nano Aerogels Synthesized in Supercritical Ethanol". SN Applied Science, vol. 2, 872, 2020.

[12]. P. D. R. Setya, and Z. Mochamad. "Pengaruh Waktu Tahan Proses Kalsinasi Prekursor Silika sebagai Material Pelapis Hidrofobik". Jurnal Sains dan Seni ITS, vol. 5, no. 2, 2016.

[13]. E. D. Rakhmawaty, N. A. Rostika, and J. Dini. "Sintesis Silika Metode Sol-Gel Sebagai Penyangga Fotokatalis $\mathrm{TiO}_{2}$ Terhadap Penurunan Kadar Kromium Dan Besi”. Jurnal Sains Materi Indonesia, vol. 17, no. 2, 2016.

[14]. A. Sulistyono, S. Wahyuni, and Kasmui. "Sintesis dan Karakterisasi $\mathrm{TiO}_{2}$ (Nanorod)- $\mathrm{SiO}_{2}$ dan Aplikasinya dalam Cat Akrilik”. Journal of Chemical Science, vol. 7, no.1, 2018.

[15]. S. Phromma, T. Wutikhun, P. Kasamechonchung, T. Eksangsri, and C. Sapcharoenkun. "Effect of Calcination Temperature on Photocatalytic Activity of Synthesized $\mathrm{TiO}_{2}$ Nanoparticels via Wet Ball Milling Sol- Gel Methode". Journal of Applied Science. vol. 10, 2020.

[16]. D. C. Hermawan, T. Haryati, and E. Supriyanto. "Pengaruh Pelarut dan Ukuran Template Terhadap Struktur $\mathrm{TiO}_{2}$ ". Jurnal Kimia. vol. 2, pp. 91-93, 2017.

[17]. Astuti, and N. Sulastriya. "Sintesis Dan Karakterisasi Nanopartikeltitanium Dioksida $\left(\mathrm{TiO}_{2}\right)$ Menggunakan Metode Sonokimia”. Jurnal Ilmu Fisika, vol. 9, no. 1, 2017. 
[18]. N. Andi. "Sintesis Nanopartikel Mangan Dioksida $\left(\mathrm{MnO}_{2}\right)$ Secara Sonokimia Sebagai Adsorben Ion Logam Kadmium $\left(\mathrm{Cd}^{2+}\right)$ ". Skripsi. Makassar: Jurusan Kimia FMIPAUIN Alauddin Makassar, pp. $15-18,2017$

[19]. A. Mehdi and E. Ebrahim. "Sol Gel Synthesis of $\mathrm{TiO}_{2}$ Nanostructured Film on $\mathrm{SiO}_{2}$ Pre-coated Glass with a Comparative Study of Solvent Effect on the Film Properties". Journal of Sol Gel Science Technology, pp. 1-11. 2016.

[20]. K. Prasad, D.V. Pinjari, A.B. Pandhit, and S.T. Mhaske. "Synthesis of Titanium Dioxide by Ultrasound Assisted Sol Gel Thenique: Effect of Calcination Temperature and Sonication Time". Journal of Ultrasonics Sonochemistry, vol. 23: pp.
185-191, 2015.

[21]. Y. Ren, W. Li, Z. Cao, Y. Jiao, J. Xu, P. Liu, S. Li, and X. Li. Robust $\mathrm{TiO}_{2}$ nanorods-SiO 2 core-shell coating with high-performance self-cleaning properties under visible light. Applied Surface Science. 2020

[22]. W. A. Akustia, Nuryono, and K. Indriana. "Waterrepellent glass coated with $\mathrm{SiO}_{2}-\mathrm{TiO}_{2}-$ methyltrimethoxysilane through Sol-Gel Coating". AIMS Materials Science, vol. 6, no.1, pp. 10-24, 2018.

[23]. R. Agus, and W. Sri. " $\mathrm{TiO}_{2}-\mathrm{SiO}_{2}$ Modified on Acrylic Paint with Self- Cleaning Characteristics," in Proc. of The 9th Joint Conf. on Chem, pp. 3-7, 2015. 